Litinfinite Journal

ISSN: 2582-0400 [Online]

CODEN: LITIBR

Vol-1, Issue-2 (2 ${ }^{\text {nd }}$ December, 2019)

Page No: $19-23$

DOI: 10.47365/litinfinite.1.2.2019.19-23

Section: Article

\title{
Subjugation of Women in Girish Karnad's Naga-Mandala
}

\section{Bisnu Charan Mahato}

Ph.D Scholar- Department of English, Ranchi University, Jharkhand, India

Mail Id: bisnu.charanmahato@gmail.com

\begin{abstract}
One of the Prominent playwright Girish Karnad in most of his plays, meticulously presents the ordeal of a typical Indian female, dominated and exploited by the patriarchal society while the spirit of the caged women strive for liberation from the chains of inequality, superstition, myth and tradition. In his play 'Nagamandala' (In Sankrit which means a sacred aura related to or made by naga). Karnad has dealt gender concern in his plays while exposing and criticizing the male chauvinism prevalent in patriarchal society. The author uses myths and folks in his plays to eradicate socio-cultural evils. The playwright Karnad accentuated problems of and treatment to a woman in contemporary biased patriarchal social order in his plays and exposes the prevalent double standard towards women in patriarchal society.
\end{abstract}

Keywords - Subjugation of Women, Patriarchy, Nagamandala, Indian English Drama, Indian English Literature

Naga-Mandala is a beautifully woven play of two folklores passed and perpetuated through generations in Karnataka. It is a story within story or even a story told by a story, where myth meets superstition, magic and supernatural powers. Fact and fantasy blend together during making and breaking of the dreams of Rani. The particular character becomes the general as it is evident since the very opening line of the story "A young girls her name.... it doesn't matter." Although the name of the girl is itself ironic as Rani means "Queen" in English supposed to have certain authority and respect but she is degraded into merely a maidservant or even an imprisoned one by her husband Appanna (literally 'means any man'). She is even ignorant of sex and deprived of her nuptial rights, life of dignity and opportunity of becoming a mother.

\section{The Exclusion of the 'Second Sex'}

The basic dramatic depiction of the play presents Rani, an overprotected submissive girl, who becomes the victim of an unjust social order through marriage at a very early age. Although thankfully she stays with her parents till she attains adulthood, she never gets any chance of discovering herself, or to grow and develop as human being while realizing her true potentials. Rani's subjugated position gives her no relief: either at her parent's house or at the house of her husband. Marriage, especially child marriage or marriage at a very early age has been used to exploit, oppress and torture women in a patriarchal society. Newlywed girls are forced to think of their husbands to be the all and all of their lives. They are expected to be chaste or even be dominated to undergo chastity test while their husband can be a philanderer or a womanizer. 
Locked up in the house as a caged bird, Rani could find solace only in delusion of her parents' presence. She helplessly dwells into the world of fantasy to fulfil her desires in the absence of social interaction and articulation. She is neglected sexually, beaten and bullied physically, mentally tormented by the uncertainty and indifference from Appanna. She longs for freedom and pines for love. She is ostracized to the point of being mad. Her anguish can be felt by her statement in front of Kurrudavva. She is never heard, never allowed to live the life as a dignified member of the society. As Simone de Beauvoir asserts that

"Marriage is not only an honourable career and one less tiring than many others: it alone permits a woman to keep her social dignity intact and at the same time to find sexual fulfilment as lived one and mother". (Beauvoir, 62)

In contrast here, the patriarchal society always subjugates and treats a woman as a 'second sex'.

\section{The Helpless Women}

The women portrayed in the play lack independence and self-reliance. Her father thinks that Appanna is a perfect match for Rani. Rani dreams of her marriage as a pious relationship and she goes to her husband's house with the manifestation of simple dreams that she would lead a happy domestic life. It is a paradox that a Woman is called homemaker but neither her parents' house nor her husband's house is called her house. Home is said to be her expression of freedom but here she is permanently caged hi her own husband's home. Therefore Rani as a daughter is dependent on her parents for shelter, protection as well as decision making prior to marriage. After marriage, as a wife she is dependent on her husband. The only matron Kurrudavva is also a handicap without her son Kappanna.

\section{The Paradox}

The paradox in the play is the behaviour of Rani's husband Appanna and that of the Naga. One is human but not humane, other is not human but humane. One is indifferent to his own wife and gallivants after the concubine. Other one is 'love struck' by the effect of the 'love root' not only expresses his tender love to Rani, but also renders Rani with the opportunities to become a wife, a mother and a woman while her husband who is entitled to and entrusted with these responsibility fails to do so. Karnad's concept of 'Transposed heads' in 'Hayavadana' is replaced by 'Transposed personalities.' The behaviour of the Naga in contrast with that of Appanna symbolizes the poisonous attitude of hypocritical society towards women.

The indifference and apathy of Appanna takes Rani to the verge of insanity. She is forced to take refuge in dreams, fairy tales and fantasies to escape the morbid situation. Appanna is busy in self-gratification in illegitimate way but refuses to acknowledge the physiological, psychological, intellectual and social needs of Rani. 
Litinfinite Journal

ISSN: 2582-0400 [Online]

CODEN: LITIBR

Vol-1, Issue-2 (2 ${ }^{\text {nd }}$ December, 2019)

Page No: $19-23$

DOI: 10.47365/litinfinite.1.2.2019.19-23

Section: Article

\section{The Taboo and the Tool}

The Story reaches to its climax when Rani becomes pregnant. The hypocritical patriarchal society subjects her to undergo a chastity test to establish herself as pure, while Appanna who himself is indulged in illicit relationship with the concubine escapes any such judgment. Here the chastity can be a value invented by patriarchal culture and imposed on women as one of the most powerful tool to enslave them in a patriarchal society. There are ample of literature to glorify this enslaving value and the women who observed this submissively. 'Sita' of 'The Ramayana' has always been presented to guide this submission.

The hypocrisy of the patriarchal society is unearthed in another concept which goes with the concept of chastity, i.e. Sex is sin, the patriarchal society some time directly through moral teaching or indirectly through treatment shows that chastity is more important than life and that its loss which brings an unbearable social stigma is worse than death. There have been historical evidences where we derive several specific historical meanings. On the one hand, it relates to forms of sexual abstension and it highlights the sanctity of marriage only for the method of procreation or giving birth to a child. As philosopher David Hume pointed out in his discursive and incessant idea about social mores, childbirth and fidelity in A Treatise on Human Nature, a man only wants to support a child he is related to biologically. In order to remain sure about the paternity of the child, he has to primarily ensure that his wife is dedicated and loyal to him. In the process, what was found was that, woman's liberty and sexual expression was curtailed to a large extent for this reason. In case of the Indian society, what we find is that, the double standard of contemporary patriarchal society idolizes the pornstars who serve the male chauvinism but condemns the rape victims who are made to suffer unbearable humiliation and disgrace for crimes committed by somebody else against them, this way this chastity convicts the innocent rape victim with double punishment for no fault at all.

Committing adultery by the husband in the play is not taken as a social inequity because even the village elders administer a positive response in relation to the male system of adultery. The village court tries the case of Rani only and it ignores the crime of Appanna that highlights the gender-bias and the optimum futility of justice. Nobody believes in the innocence of Rani.

Rani sleeps with Naga as Naga comes to her every night in guise of her husband, whatever follows happens only because Rani is never allowed to question her husband during the day and Naga during the night. This demand for submission without reasoning keeps Rani ignorant.

Had she discovered the real identity of Naga, she would not have allowed him to enter her bedroom touch her. As a typical Indian woman, she is frigid and she detests sex. What she craves for is love and affection which only Naga could give her. By Praising, caressing and arousing, Naga removes her frigidity.

\section{The Ascension of the Woman}


When we start dissecting the premonition about the birth and growth of the new woman, as the play gradually draws towards its point of crisis, we find from the dogmatic purview of what Rani was earlier, she gradually flourishes into a confident and courageous woman who has reason and rationality in thinking. She admits that she is not a talking and obeying parrot anymore, and nor is she the stupid, ignorant girl. She somehow again becomes what she was at the beginning of the play: queen of the whole world, queen who is equipped with long, thick flowing hair. She $\mathrm{n}$ longer is involved in the 'rotting of the brain which she did earlier.'

As the play draws near its end, we find that the lady protagonist regains her courage and she even stands against the dictum that is given by the village professionals:

"If you don’t let go, I'll." (Karnad, 98).

We find a reference to the stringent concept of ablution from sin, and how the lady has to undergo a chastity test. Rani, after this, is declared as goddess incarnate and she becomes the head of the family. However, the Rani, unlike the past patriarchal Appanna, never tries to subjugate him but rather she shows her more humane and feminine side of attachment and affection. Appanna even agrees to her rather strange demand that their son should perform the annual rites in the memory of the dead snake. Since she is part of a predicament, it is also her duty to take her family out of the situation of predicament. There are cases of sexual gratification, but there are also cases of creating a subtle, unique space for the woman who undergoes various processes of self-realization. If it is a test about fire, she gives in, if it is a test about chastity, she ensures it and gets out triumphant. In this connection, it would be most appropriate to consider what Shulamith Firestone has argued in her major work The Dialectic of Sex (2015) that the entire concept of society is not natural and extremely stratified. It is this constant discourse of the dichotomy between the gendered norms and cultural patterns that man and woman share a bonding only for procreation and that is the reason also why the woman is considered to be less beneficial at multiple levels. Hence what we see in Nagamandala are the men who seek sexual gratification from women, they denigrate their levels and even when the village elders allow her to have a space of her own, the husband's private self becomes more linked with the public self. There is a constant need for support and fulfilment. It is not about the tragedy that we try to locate the generalized notions of the woman, but it is in the revisiting of the female self with scars, wounds, and marks of chastity that the woman changes form and content.

\section{How do we find the role of love and lover to be?}

The Naga dies after entering Rani's bedroom, and somehow the latent desires, potential ideas of backbreaking spirit in recovering the lost glory of the woman is lost in the indigenous acceptance of the husband once more. We do not find a defeated Rani, but we find how the lover in the form of the snake is always present and there is a definite inextricable bond between the two. The danger to male authority as a husband and patriarch lives on constantly at close quarters, but meeting within the woman's imagination. There is a meeting that starts with the difference, and gradually when Rani finds in the mirror that the person who comes to her during day, and during night are completely different, she understand the conflict and the climax that her life is going to take. It may be worthwhile to mention about Freud's analysis 
CODEN: LITIBR

Vol-1, Issue-2 (2 ${ }^{\text {nd }}$ December, 2019)

Page No: $19-23$

DOI: 10.47365/litinfinite.1.2.2019.19-23

Section: Article

of the snake in this direction. Snake as related to the latent and the repressed desires that are completely hidden and mixed with the primal impulses of the soul, and on the other hand, Lacan has exhorted on the overall implication of the mirror stage, reflection and the desires in their definite directions. As the woman begins to grow, she realizes that:

"No two men love alike, and that night of the village court, when her true husband claimed into led with her, how could she fail to realize it was someone new?... Don't you think she must have cried out in anguish to know the answer?" (Karnad, 41)

It is this anguish that becomes even more conspicuous than the learning methodology that she undergoes as a part of the ritualistic marital procedure. When she looks into the mirror, she finds that no two men are the same, but with each of them we find the mandala or the centre that is growing in and around her. Even the Naga's injunction is so strict that Rani fails to realize till a certain point that the Naga is not different from her own husband. It is the difference that arises between the knower and the source of knowledge and this gets sustained all throughout the play. There is no cosmetic role-playing that we see even in the text and even on stage there is a reference to how a woman, in spite of her innocence, has to undergo a rigorous test for proving why she let one man intrude into her space that was previously occupied by her husband.

The radical female protagonist is the most noteworthy feature of Girish Karnad's play. In 'Naga-Mandala' Girish Karnad has created the character of Rani in unconventional way. This character desires to achieve what she lacks, riots against the patriarchy and maledominance, strives for survival and destroys traditional concepts with the belief of transformation in the attitude of the male-dominated society. The play creates a question mark on the entire danger that lurks in the larger vortex of understanding the woman question. It is about Rani and it is also about the dual and later the tripartite relationship that she shares and yet she becomes the central point of dominance and discussion only at the very last moment. It is not Rani's triumph that we look at, but on the contrary, we keep on dissecting the entire formative and the growing phases of what Gender study and women's movements have been teaching us for a long time.

\section{Works cited:}

i. Karnad, Girish. "Naga-Mandala: A Play with a Cobra". New Delhi: Oxford University Press, 2004.

ii. Beauvoir, Simon de. "The Second Sex".New York: Vintage Books, 1997

iii. Roy, Janardana. "Girish Karnad's 'Naga-Mandala' - A Challenge to the Patriarchal Moral Code", International Journal of English Language, Literature and Humanities. 4 (5), pp. 641-647, May 2016

iv. Hume, David. A Treatise on Human Nature. Oxford: Oxford University Press, 1990.

v. Firestone, Shulamith. The Dialectic of Sex. New York: Verso Books. 2015. 